\title{
The Impact of Chinese Investment in Africa
}

\author{
Kinfu Adisu \\ Grand Valley State University, 1 Campus Drive \\ Allendale, MI 49401-9401, USA
}

Thomas Sharkey

College of Business Administration, The University of Toledo

2801 W. Bancroft Street, Toledo, Ohio 43606-3390, USA

Tel: 419-530-2285 E-mail: Thomas.sharkey@utoledo.edu

Sam C. Okoroafo (Corresponding author)

College of Business Administration, The University of Toledo

2801 W. Bancroft Street, Toledo, Ohio 43606-3390, USA

Tel: 419-530-4398 E-mail: sam.okoroafo@utoledo.edu

\begin{abstract}
The purpose of this paper is to explore the increasingly important economic and business relationship between the People's Republic of China and the countries of Africa. Our focus is on how this partnership manifests itself in investments. The research questions are: first, how has the relationship changed over time and second, from an African perspective has this relationship been beneficial? Finally, how has the recent economic downturn affected their partnership? Our investigation shows that Chinese investment has been motivated by a desire to access critical resources (oil, bauxite, etc.). The Chinese approach was been to downplay political issues (e.g., human rights). Although recipient African nations have received investment inflows, they have come with certain drawbacks. For instance, they have negatively impacted local trade and commerce. Also, in some cases African labor has not benefited from Chinese investment.
\end{abstract}

Keywords: Investments, China, Africa, Resources, Minerals

\section{Introduction}

\subsection{Phases of Engagement}

Historical evidence show that there have been economic and political relationships between China and Africa as far back as 500 years ago (Mohan and Kale, 2007). A profound increase in the last two decades may have been related to the shifts in the world economy, geopolitical competition, and changes in Chinese foreign policy (Brautigam, 2003). According to Mohan and Kale (2007), the Chinese-Africa business contact is divided into three phases. The first phase from 1850 to 1950 related to colonial labor demand called "coolie trade." Coolie trade focused mainly on plantation, mining, and railway construction. Alongside this were small but enterprising businesses that serviced Chinese labor markets and undertook small-scale export. The second period was from 1960-1980. With the establishment of the People's Republic of China and the subsequent cold war, relations between China and Africa became political. China challenged the superpowers through foreign aid to Africa in order to cement 'South-South' relations. It also encouraged the independence movement in Africa. This is also when Chinese economic reforms were being instituted allowing liberalization, special economic zones, and permitting foreign direct investment (Shenkar, 1994). The last period is from 1990 to present, most noticeable in the last 5 years. According to Broadman (2007), there has been movement of Chinese companies into African countries particularly in the areas of construction, mining, and oil extraction. Such efforts have been encouraged by the Chinese government.

\subsection{Conferences}

One of the cornerstones of Chinese-African relationship began after the Bandung conference in 1955 (Muekalia, 2004), in which, "China began to cultivate ties and offer economic, technical, and military support to African countries and liberation movements in an effort to unite with them against both superpowers" (pp. 6). This 
strategy was also reflected at the first ever China-Africa Co-operation Forum held in Beijing from October 11-12, 2000, in which 44 African countries and 80 ministers were present. According to Muekalia (2004), the forum expressed a clear policy goal for dealing with African countries. It involved co-operation on investment, financial operations, debt relief and cancellation, agricultural, natural resources and energy, education, and multilateral matters. Anshan (2007) also reiterates this, explaining how the new Chinese approach enhanced its relations with Africa in many ways including educational, cultural, medical, public health support and training.

\subsection{Motives}

In view of the above aid strategy, one may suggest the main motive for Chinese relationship is to gain access to the abundant raw materials that Africa offers. Although this may be a good reason, Alden (2005) states that China's insistence on recognition of its "one China" policy by Africans as another important requirement. Alden (2005) also lists four factors that have shaped China's contemporary African policy: China's need for energy security; new market and investment opportunity; symbolic diplomacy and development; and forging strategic partnerships. According to Konings (2007), the main drivers of the China-Africa cooperation is defined by recent statement by Chinese government on two issues. One is on cooperation, "China will continue to strengthen solidarity and cooperation with African countries in the international arena, conduct regular exchange of views, coordinate positions on major international and regional issues and stand for mutual support on major issues concerning state sovereignty, territorial integrity...." (pp. 360) The other one is the fact that "The one-China principle is the political foundation for the establishment and development of China's relations with African countries and regional organizations." (pp. 361). Zweig and Jianhai (2005) concluded that China's African policy is being driven by its domestic development strategy. First, it wants to access energy resources. Second, it wants to establish export markets for its light manufacturing, services, agro-processing, apparel, and communications offerings. Already, Africa is full of low-cost motorcycles, electronic and consumer goods sourced from China.

\section{Chinese Investment Model}

According to Sautman and Hairong (2007), there are factors that made China's relationship with Africa distinctive. Other than aid and migration policies, the "Chinese model" of investment and infrastructure loans known as the "Beijing Consensus" is a very important approach that needs to be discussed. In Ramos's (2004) terms, it is a new attitude towards politics, development, and global balance of power. In general, it values the political and international relations concept of multilateralism, consensus and peaceful co-existence (Wenping, 2007). This approach contrasts with Washington consensus, a neo-liberal paradigm that takes into consideration democracy, good governance, and poverty reduction (Fine and Jomo, 2005- in Sautman and Hairong, 2007).

The Chinese model of investment in essence brings economic growth objectives and foreign policy together guiding trade and invest decisions in Africa along with "no strings attached" financial and technical assistance (Zafar, 2007). Chinese bid competitively for resource and construction projects using investment and infrastructure loans. These loans are often advanced at zero or near-zero percent interest or allow for repayment in natural resources (Brautigam, 2003). For example, China offered US\$2 billion in aid for infrastructure projects, thereby securing a former Shell Oil block in Angola by outbidding an Indian proposal. In a similar case, a Chinese firm promised US\$7 billion in investments and rehabilitation of power stations to secure an oil area sought by western corporations (Alden and Davies, 2006). Many Africans view Chinese investment as different from the western investment. According to This Day (2005), the Chinese are not imposing the neo-liberal package of reform usually required by the World Bank under its "conditionality provisions." Chinese aid by contrast comes without strings attached and is seen as supporting initiatives by African states to address development issues not solved by Western investment (Sautman and Hairong, 2007).

\section{Chinese Investment in Africa}

Africa, according to Sautman and Hairong (2007) has the highest return on FDI, ranging from 29\% in 1990 to $40 \%$ in 2005. Although China's trade with Africa is small compared to US\$1.76 trillion in world trade, it has grown from US\$3 billion in 1995 to US\$55 billion in 2006. It is predicted that Chinese investment will top the US $\$ 100$ billion mark by the end of the decade (Taylor, 2006). As evidence of this trend, there are more than 800 Chinese companies in Africa in 2006, one hundred of which are medium to large state owned firms (Xinhua, 2007).

According to Kaplinsky, McCormick and Morris (2007), China is having a profound impact on African economies. The increasing economic expansion is particularly evident in Sub-Saharan Africa. In the last decade, the Chinese have built a network of trade, aid and investment with close to fifty countries (Zafar, 2007). Chinese companies are mining oil in Angola and Sudan, building roads in Ethiopia, generating electricity in Kenya, 
building infrastructure and encouraging tourism in Sierra Leone, and servicing mobile phones in Kenya and Nigeria. China's rapidly developing oil consumption seems to have a bigger effect on Chinese-African trade (Taylor, 2006; McLeary, 2007). This is the main reason behind the whole raft of new contracts between 2002 and 2006. During this period, Chinese oil companies have signed deals to buy refineries and explore oil and gas in Algeria, Gabon, Angola, Nigeria, Ivory Coast, Kenya, Congo Brazzaville, Namibia, Ethiopia, Madagascar and Sudan. Additionally, China also helped in treating infectious diseases such as malaria and HIV/AIDS and launched the first overseas radio station in Kenya (Brooks and Shin, 2006). Recently, China and Nigeria just signed a major oil deal worth US\$23 billion (Swartz and Hall 2010). It calls for China to build three refineries in Nigeria.

As a result, trade between them has increased making China the continent's third largest trading partner after the European Union and the US. China has continued to push closer ties with Africa and has awarded US\$10 billion in aid for the next three years and dispatched volunteers to provide medical assistance and build hospitals and schools (Ewing, 2009). As Tull (2006) explains, Western criticisms of China's human rights record and other international issues have induced the Chinese to seek closer ties with non-western nations in an effort to build international coalitions.

\section{African Perspective: FDI Effects}

Unlike their national leaders who are supportive of partnerships, China's increased presence in Africa has been questioned by several African scholars and societal organizations (Konings, 2007). While some scholars see China's economic growth as a positive development model for the third world (Alden, 2005), others look more critically at China's behavior on the continent and sees its parallels to the neo-colonial past (De Lorenzo, 2007). We will use the Hood and Young (1981) model that evaluate multinational activity based on social, competitive, trade, etc. criteria.

\subsection{Social Effects}

Assessing the advantages and disadvantages of Chinese involvement in Africa may not be so simple. Africa's economic growth of 5.8 percent in 2007, the highest ever may partially be attributed to Chinese investment (Hanson, 2008). It has cancelled debt worth US $\$ 10$ billion from African countries, sent doctors to treat Africans, and hosted thousands of African workers and students in their universities and training centers. In addition, the roads, bridges and dams built by China are important contributors to the continents infrastructure. On the other side, the relationship has emboldened the governments to limit their progress towards political and economic reform.

\subsection{Trade Effects}

There are even more controversial points however. These are related to the trade, commerce, and social areas. According to Kaplisky and et al. (2007), in trade, especially Sub-Saharan Africa is impacted in two ways. One aspect is the competition in internal markets for domestically-oriented manufacturers, and another is competition in external markets from export-oriented industry. The balance of trade favors China as local industries and merchants have been hit hard by the flood of cheap Chinese wholesale and retail shops used to establish networks to sell goods (Alden, 2005, pp 156). Moreover, African producers cannot compete with Chinese companies even in African markets since Chinese manufacturers have low production cost and market prices (Tull, 2006).

\subsection{Competitive Effects}

The use of Chinese labor, rather than local workers in Chinese sponsored projects in Ethiopia, Sudan and Namibia has been criticized locally (Alden, 2005). De Lorenzo (2007) also reiterates that, what is worrisome is the impact of Chinese competition on African enterprises and exports. In Nigeria, the imported textiles have forced local factories to close. However, South Africa is not affected as much because of temporary bilateral agreements between the governments that limit Chinese imports.

\subsection{Unemployment Effects}

The challenges are not limited to the competition. According to Anshan (2007), with the flow of goods from China, conflict over labor practice and market strategies is turning out to be an important issue. The preference to hire Chinese nationals and long hours of work expected by Chinese managers is causing conflict with local labor laws and cultures. In addition, company practices lead to discontent in communities who perceive that Chinese companies are not contributing enough to increase local employment and strengthen the local economy. Another conflict is the quality of Chinese goods which is cheaper and of better quality than locally produced ones. 


\subsection{Moral Effects}

Zweig and Jianhai (2005) stated that "Beijing's resources-based foreign policy has little room for morality" (pp. 31). After all, some of the very rich resources are found in nations with a history of ineffective governance. China has established relations with rogue nations, at times mired with violent reactions from the citizens of those nations. Some examples can be found in their experiences in Sudan, Nigeria, Ethiopia, and Zambia. For instance, in Zambia's copper belt of Chambishi protesting employees were sprayed with gunfire by Chinese supervisors (Trofimov, 2007).

\section{Dunning Eclectic Model and China's African FDI}

In an attempt to better explain China's foreign direct investment in Africa, Dunning's eclectic model will be presented. This model was deemed appropriate because it addresses the key aspects of this relationship. According to Dunning (1980), in its original form the eclectic model is based on three sets of advantages considered important by the firms. One, for MNEs to compete by producing in another country must have advantages specific to their ownership. While these advantages are considered competitive or monopolistic, it must be able to compensate for the cost of setting up and operating compared to the local competition. Two, it must be in the best interest of the firms that have ownership advantage to transfer resource within their own firms, rather than sell them or the right of use to foreign based enterprises. The third one is concern is ensuring that location of production is in the best interest of the firm. As pointed by Dunning (1980), "while, in the eclectic paradigm, the advantage or disadvantages of particular locations are treated separately from ownership advantage of particular enterprises, and the market for these advantage are internalized; the decision on where to site a mine, factory or office, is not independent of the ownership of these assets nor of the route by which they or their rights are transacted" (pp. 4). Additionally, as has been seen above, Chinese foreign policy aims are a critical determinant of its investment and foreign aid, since firms are not necessarily independent of the Chinese government.

Investments by Chinese companies in Africa are advantageous to them because they face limited domestic and foreign competitors. But it faces greater risk since the general environmental conditions including political and economic are continuously changing. These factors, in addition to the absence of public goods needed to overcome government and market failure, are creating a unique situation that made it unattractive for other investors (Bartels, Alladina, and Lederer, 2009).

\section{Impact of the Global Financial Crisis (2008-present)}

In light of the above discussion one may contemplate, how the Chinese investment and policy towards Sub-Saharan Africa is affected by the global financial crisis. It is reasonable to begin this topic with a discussion of the world economy since that is where the ripple effect started. IMF (2009) reports indicate that the current financial crisis is global and the world is facing a deep downturn. The January 2009 report(IMF) of the World Economic Outlook projected, world economic growth to slow to less than 3.5 percent in 2008 to about 0.5 percent in 2009 before recovering in 2010. Similarly, growth is expected to fall in China and other emerging market economies from 6.25 percent in 2008 to about 3.25 percent in 2009 because of falling export demand, suppressed capital inflows, and lower commodity prices. Obviously, this economic climate will have direct impact on African economy considering "China is a major market, financier, investor, contractor, and builder as well as donor" nation (Wang and Bio-Tchane, 2008, p. 1). According to a report from Idun-Arkhurst and Laing (2007), although African economies were stagnant during the 1990s, during the last three years Africa has sustained steady growth. This growth has been driven by global demand for oil and raw material. Africa's output grew by estimated 5.5 percent in 2006 and projected to grow at 5.9 percent in 2007 , but falling slightly to 5.7 percent in 2008. UNCTAD reports the global demand for raw materials has shown a twenty-five percent increase in FDI in Africa with $\$ 39$ billion invested in 2006 mainly in the extractive sector (Idun-Arkhurst and Laing, 2007). In the mean time, Chinese economy grew an average of 9 percent per year in the last 25 years and predicted to reach as high as 13 percent. The two way trade between China and Africa has been growing. Wang and Bio-Tchane (2008), report that between 2001 and 2006 Africa's exports to and imports from China grew by an average of 40 percent and 35 percent. In dollar terms the increase was from US\$10 billion to US $\$ 55$ billion, making China the third largest trading partner after U.S and the European Union.

Both China and Africa have to cope with the impact of the global slowdown. Although there are a signs of recovery, some African countries are still vulnerable to the slow economic growth of the developed world (Moin, 2010). According to the World Bank (Kang \& Gongzheng, 2009), the rate of growth in sub-Saharan Africa is projected to be 1.5 percent in 2009 compared to 5.5 in previous year. China is also affected by the crisis. The growth rate was 7.7 in the first quarter of 2009 , compared to 8 percent in the previous year. Currently, it appears 
that China is doing better than projected as it reported an 11.5 percent growth rate for the first quarter of 2010 (Bloomberg, 2010).

So, is China's investment and aid plans interrupted because of the global financial crisis? According to the Forum on China-Africa Cooperation, Beijing Summit in 2006, China promised to increase investment and aids to Africa by three fold (Xinhua, 2009). In the words of Premier Jiabao, "whatever change may take place in the world...our policy of supporting Africa's economic and social development will not change"(Xinhua, 2009 pp. 2). Since 2000 China-Africa trade investment grew by rate of 33.5 percent, reaching US $\$ 106.8$ billion by 2008 beating the target set by Beijing summit two years ahead of schedule (Wallis, 2010; Xinhua, 2009). In fact, the Chinese funding of infrastructure and development in Africa grew to rival lending by World Bank and International Monetary Fund.

\section{Discussion}

There has been a substantial growth in the relationship between China and Africa. The Chinese strategy is working for both parties in many ways, especially in investment, foreign aid and debt forgiveness. This is impressive given the very different cultures and agendas of these countries. Chinese investment has not, yet, begun to rival western investment, but that in no way diminishes the significant strides that have been made and there seems to be a commitment to continue this forward momentum.

From an African perspective, Chinese investment has been good in many situations, but as with other investments it comes with a substantial price. The price includes dominance of local culture and considerations. It has also negatively impacted local trade and commerce. In some cases, African labor has not benefited from Chinese investment. Finally, Chinese investment has propped up some rogue regimes.

It is too early to tell if the world-wide recession has negatively affected Chinese investment. Clearly, the Chinese have a strong track record of investing in Africa and rhetorically they support continued development. As more data becomes available, it will be very interesting to see if there are any changes in these patterns.

Theoretically, Dunning's economic framework seems to do a good job of predicting Chinese investment. A clear example of this is in extraction industries. The Chinese are especially concerned about oil. The addition suggested here is the addition of the influence of the Chinese government to the decision making process.

\section{Conclusions}

In conclusion, while Chinese relations with African countries have been positive in some ways, serious questions are being asked by Western and African intellectuals about China's tactics and strategies in its quest for resources. Unfortunately, many authoritarian African leaders have actually embraced the Chinese model allowing them to maintain a strong grip on political power (Brooks and Shin, 2006). Economy and Monaghan (2006) also mentioned that African leaders cite China as the ideal model for their countries and economies.

The current recession has focused the world's attention on financial problems from Iceland to Greece and from the US to Japan. Somewhat overlooked in this downturn is the relationship between Africa and China. Clearly, this is a very important relationship on many different levels and should concern western business and governmental interests.

This relationship is likely to endure since both parties benefit to some degree. This is important to some African countries since it provides a different development model and different rules of the game put forward as the "Beijing Consensus," with its strong commitment to Africa. It is also attractive because it does not prescribe behavioral outcomes for African leadership. The Chinese seem willing to work with the African governments and have rejected criticisms. They are not apologizing for their activities (Wu 2010) and claim that the investments are now more 'market driven.'

\section{Limitations}

The limitations of this study include its conceptual nature. None of the conclusions have been supported by quantitative or statistical analysis. So, most of the views are clearly those of the authors. Africa has been addressed at the macro level rather than on a country by country basis. Each African country has a unique and important history and culture (cultures) that is not picked up in this kind of analysis. Finally, getting solid numbers for Africa is always a difficult process and in this case did not assist in evaluating the impact of the recession.

\section{References}

Alden, C. (2005). China and Africa. Survival, 47(3), 147-164. 
Alden, C., \& Davies, M. (2006). A profile of the operations of Chinese multinationals in Africa. South African Journal of International Affairs, 13(1), 83-96.

Anshan, L. (2007). China and Africa: Policy and Challenges. China Security, 3(3), 69-93.

Bartels, F., Alladina, S., \& Lederer, S. (2009). Foreign direct investment in Sub-Saharan Africa: Motivating factors and policy issues. Journal of African Business, 10, 141-162.

Bloomberg (2010). China's GDP Growth Rate. [Online] Available: http://www.tradingeconomics.com/Economics/GDP-Growth.aspx?Symbol=CNY

Brautigam, D. (2003). Close encounters: Chinese business networks as industrial catalysts in Sub-Saharan Africa. African Affairs. 102, 447-467.

Broadman, H. (2007). Africa's Silk Road: China and India's new economics frontier, World Bank, Washington DC.

Brooks, P., \& Shin, J. H. (2006). China's influence in Africa: Implications for the United States, Backgrounder, No. 1916, Published by Heritage Foundation.

De Lorenzo, M. (2007). African Perspective on China. American Enterprise Institute for Public Policy Research, Wed. October 3, 2007.

Dunning, J. H. (1980). Toward an Eclectic Theory of International Production: Some Empirical Tests. Journal of International Business Studies, 11(1), 9-31.

Economy, E., \& Monaghan, K. (2006). The Perils of Beijing's Africa Strategy. The International Herald Tribune, 7 November 2006.

Ewing, K. (2009). China's new 'win-win' strategy in Africa. [Online] Available: http://atimes.com/atimes/printN.html

Fine, B., \& Jomo, K.S. (2005) -in Sautman, B., \& Hairong, Y. (2007). Friends and Interests: China's distinctive links with Africa. African Studies Review, 50(3), 75-114.

Hanson, S. (2008). China, Africa, and Oil. Council on Foreign Relations. [Online] Available: http://www.cfr.org/publication/9557/china_africa_and oil.htm.

Hood, N., \& Young, S. (1981). The Economics of Multinational Enterprise. Longman: London

Idun-Arkhurst, I.I., \& Laing, J. (2007). The impact of the Chinese presence in Africa. [Online] Available: www.africapractice.com

IMF. (2009). Impact of the global financial crisis on Sub-Saharan Africa. IMF Multimedia Services Division.

Kang, F., \& Gongzheng, C. (2009). China-Africa cooperation defies hard times. [Online] Available: http://news.xinhuanet.com/english/2009-11/06/content_12400149.htm

Kaplinsky, R., McCormick, D., \& Morris, M. (2007). The impact of China on Sub-Saharan Africa, Working Paper 291, Institute of Development Studies.

Konings, P. (2007). China and Africa: Building a strategic partnership. Journal of Developing Societies, 23(3):341-367

McLeary, P. (2007). A different kind of great game: Are China and United States heading for a showdown over Africa? [Online] Available: www.foreignpolicy.com printed on 3/30/2009

Mohan, G., \& Kale, D. (2007). The invisible hand of South-South globalization: Chinese migrants in Africa. A Report for the Rockefeller Foundation prepared by The Development Policy and Practice Department, The Open University, Milton Keynes, MK7 6AA, UK.

Moin, S. (January, 2010). Africa bruised, not battered. African Business, 360, 28-29.

Muekalia, D. J. (2004). Africa and China's strategic partnership. African Security Review, 13(1).

Ramos, J. C. (2004). The Beijing Consensus. In Zafar, A. (2007). The growing relationship between China and Sub-Saharan Africa: macroeconomic, trade, investment, and aid links. The World Bank Research Observer Advance Access.

Sautman, B., \& Hairong, Y. (2007). Friends and Interests: China's distinctive links with Africa. African Studies Review, 50(3), 75-114. 
Shenkar, O. (1994). The People's Republic of China: Raising the bamboo screen through international management research. International Studies of Management and Organization, 24(1-2), 9-34.

Swartz, S., \& Hall, S. (2010). Nigeria, China Sign Major Oil deal. Wall Street Journal, May 15, 2010

Taylor, I. (2006). China's oil diplomacy in Africa. International Affairs, 82(5), 937-959.

This Day (August 12, 2005, Nigeria). Can Nigeria be Africa's China?

Trofimov, Y. (2007). New Management: In Africa, China's expansion begins to stir resentment; Investment boom fuels 'Colonialism' charges; A tragedy in Zambia. The Wall Street Journal, Feb 2, A1.

Tull, M. D. (2006). China's engagement in Africa: Scope, significance and consequences. Journal of Modern African Studies, 44(3), 459-479.

Wallis, W. (January, 2010). Africa: Chinese investment has put Africans in the driving seat. [Online] Available: http://www.ft.com/cms/s printed: 2/22/2010

Wang, J. Y., \& Bio-Tchane, A. (2008). Africa's burgeoning ties with China. Finance and Development, A quarterly magazine of IMF; 45: 1.

Wenping, H. (2007). The balancing act of China's African Policy. China Security, 3, 23-40.

Wu, J.R. (2010). China Rejects Criticism of Investment in Africa. Wall Street Journal, April 13.

Xinhua. (2009). China-Africa trade, economic cooperation create "win-win" situation for both sides. [Online] Available: http://news.xinhuanet.com/english/2009-11/06/content_12400149.htm.

Xinhua. (February 3, 2007). Africa to be more attractive to Chinese investors.

Zafar, A. (2007). The growing relationship between China and Sub-Saharan Africa: macroeconomic, trade, investment, and aid links. The World Bank Research Observer, Advance Access.

Zweig, D., \& Jianhai, B. (2005). China's global hunt for energy. Foreign Affairs, 84(5), 25-38. 